\title{
Designing of Collagen Based Poly(3-hydroxybutyrate-co-4-hydroxybutyrate) Scaffolds for Tissue Engineering
}

\author{
S. Vigneswari, ${ }^{1,2}$ H. P. S. Abdul Khalil, ${ }^{3}$ and A. A. Amirul ${ }^{4,5}$ \\ ${ }^{1}$ Malaysian Institute of Pharmaceuticals and Nutraceuticals, NIBM, MOSTI, 11700 Penang, Malaysia \\ ${ }^{2}$ Institute of Marine Biotechnology, Universiti Malaysia Terengganu, 21030 Kuala Terengganu, Malaysia \\ ${ }^{3}$ School of Industrial Technology, Universiti Sains Malaysia, 11800 Penang, Malaysia \\ ${ }^{4}$ School of Biological Sciences, Universiti Sains Malaysia, 11800 Penang, Malaysia \\ ${ }^{5}$ Centre for Chemical Biology, Universiti Sains Malaysia, 11900 Penang, Malaysia
}

Correspondence should be addressed to A. A. Amirul; amirul@usm.my

Received 14 September 2015; Revised 17 November 2015; Accepted 17 November 2015

Academic Editor: Yakai Feng

Copyright (C) 2015 S. Vigneswari et al. This is an open access article distributed under the Creative Commons Attribution License, which permits unrestricted use, distribution, and reproduction in any medium, provided the original work is properly cited.

$\mathrm{P}(3 \mathrm{HB}-\mathrm{co}-4 \mathrm{HB})$ copolymer was modified using collagen by adapting dual solvent system. The surface properties of samples were characterized by Fourier transform infrared spectroscopy (FTIR), scanning electron microscopy (SEM), organic elemental analysis (CHN analysis), and water contact angle measurements. The effects of collagen concentration, scaffold thickness, and $4 \mathrm{HB}$ molar fraction on the hydrophilicity were optimized by the Taguchi method. The orthogonal array experiment was conducted to obtain the response for a hydrophilic scaffold. Analysis of variance (ANOVA) was used to determine the significant parameters and determine the optimal level for each parameter. The results also showed that the hydrophilicity of $\mathrm{P}(3 \mathrm{HB}-\mathrm{co}-4 \mathrm{HB}) / \mathrm{collagen}$ blend scaffolds increased as the collagen concentration increased up to $15 \mathrm{wt} \%$ with a molar fraction of $50 \mathrm{~mol} \%$ at $0.1 \mathrm{~mm}$ scaffold thickness. The biocompatibility of the $\mathrm{P}(3 \mathrm{HB}-\mathrm{co}-4 \mathrm{HB})$ /collagen blend surface was evaluated by fibroblast cell (L929) culture. The collagen blend scaffold surfaces showed significant cell adhesion and growth as compared to $\mathrm{P}(3 \mathrm{HB}-c o-4 \mathrm{HB})$ copolymer scaffolds.

\section{Introduction}

Over the years, considerable effort has been channeled in developing scaffolds for tissue engineering using biodegradable and biocompatible polymeric materials. Ideally, a scaffold should mimic the structure and biological function of native extracellular matrix (ECM) proteins, which regulate cellular activities [1].

Biopolymers which are nontoxic, noncarcinogen, nongenotoxic, and biocompatible are favoured and have been widely studied for applications in tissue engineering [2]. Among the variety of biopolymers tested, poly(3-hydroxybutyrate-co-4-hydroxybutyrate) $[\mathrm{P}(3 \mathrm{HB}-c o-4 \mathrm{HB})] \mathrm{P}(3 \mathrm{HB}-$ co-4HB) derived from microorganisms is a biocompatible material that has gained attention $[3,4]$. Despite possessing desirable mechanical and physical properties, these materials have one major drawback whereby the surface of $\mathrm{P}(3 \mathrm{HB}-$ co-4HB) is hydrophobic with no recognition sites for cell attachment that limits the applicability in the tissue engineering field $[5,6]$. Therefore, surface modifications by blending collagen to further enhance cell adhesion have been studied.

Collagen has been considered as a biomaterial for medical applications as it exhibits biodegradability, low antigenicity, negligible cytotoxicity, and the ability to support cell growth [7]. Collagen contains the peptide sequence Arg-Gly-Asp [RGD] that can be recognized by the cell surface and allows the attachment of native tissue cells to ECM that are composed of fibril proteins [8]. Blending collagen with other polymer materials may result in better properties that are more favourable for medical applications. The RGD peptide sequence found in collagen is the minimal cell-recognizable sequence found abundantly in ECM $[8,9]$. 
In the present work, $\mathrm{P}(3 \mathrm{HB}-\mathrm{co}-4 \mathrm{HB}) /$ collagen blend scaffold was prepared by facile blending via solvent casting adapting a dual solvent system to improve the hydrophilicity of $\mathrm{P}(3 \mathrm{HB}-\mathrm{co}-4 \mathrm{HB})$. The dual solvent system prevents the use of toxic solvents which are commonly used in polymer blending [10]. The effects of collagen concentration, scaffold thickness, and $4 \mathrm{HB}$ molar fraction on the hydrophilicity were optimized by the Taguchi method and significant parameters and optimal level for each parameter determined. In order to assay the cytocompatibility and cell behavior of $\mathrm{P}(3 \mathrm{HB}-$ co-4HB)/collagen scaffold, murine fibroblast cells, L929, were used to evaluate the cell attachment. Incorporating collagen onto the surface of $\mathrm{P}(3 \mathrm{HB}-\mathrm{co}-4 \mathrm{HB})$ may give new and interesting properties for applications in tissue engineering.

\section{Experimental}

2.1. Materials. The $\mathrm{P}(3 \mathrm{HB}-\mathrm{co}-4 \mathrm{HB})$ copolymers $(20,35,50$, and $82 \mathrm{~mol} \%$ ) used in this study were synthesized using wildtype and transformant strains of Cupriavidus sp. USM1020 isolated from Lake Kulim, Malaysia, in a $20 \mathrm{~L}$ fermenter as previously described [11]. Collagen powder from Tilapia fish skin (Hainan Zhongxin Chemical Co., Ltd., China) with high purity (95\%) and molecular weight of less than $3000 \mathrm{Da}$ was used. Solvents, chloroform and glacial acetic acid, were bought from R\&M Chemicals, United Kingdom.

2.2. Removal of Endotoxins Using Oxidizing Agents. Inactivation and removal of endotoxins were achieved by using hydrogen peroxide, as stated previously [12]. The copolymer $\mathrm{P}(3 \mathrm{HB}-\mathrm{co}-4 \mathrm{HB})$ produced was dissolved in chloroform $2 \%$ $(\mathrm{w} / \mathrm{v})$ at $60^{\circ} \mathrm{C}$. Three aliquots of $55 \mu \mathrm{L} / \mathrm{g}$ of hydrogen peroxide solution (30\% in water) were added to the solution at intervals of 20 minutes at $60^{\circ} \mathrm{C}$. The polymer solution was cooled and the copolymer was precipitated using methanol. The endotoxin levels were tested using E-TOXATE Kits (SigmaAldrich).

\subsection{Fabrication of $\mathrm{P}(3 \mathrm{HB}-\mathrm{co}-4 \mathrm{HB}) /$ Collagen Blend Scaffolds} by Facile Blending. Collagen powder of different weight ratios $(5,10$, and $15 \mathrm{wt} \%)$ was dissolved in glacial acetic acid solution ( $8 \mathrm{wt} \%)$. An amount of $0.42 \mathrm{~g}$ or $0.83 \mathrm{~g}$ which was previously optimized weight of $\mathrm{P}(3 \mathrm{HB}-\mathrm{co}-4 \mathrm{HB})$ copolymer was dissolved in 15 or $20 \mathrm{~mL}$ of chloroform and collagen solution was added under vigorous stirring. The solution was poured into glass Petri dish (diameter of $5 \mathrm{~cm}$ ) as a casting surface. The scaffolds were then air-dried $(24 \mathrm{~h})$ and later vacuum-dried for $48 \mathrm{~h}$ using BINDER GmbH VD 23 (BINDER GmbH, Germany) to remove any remaining solvent. The thickness of the scaffolds was measured using Teclock dial thickness gauge (Teclock, Japan). Scaffolds in thickness of $0.1 \mathrm{~mm}$ (prepared using $0.42 \mathrm{~g}$ ) and $0.2 \mathrm{~mm}$ (prepared using $0.83 \mathrm{~g}$ ) were formed.

2.4. Fourier Transform Infrared (FTIR) Spectroscopy. The FTIR spectroscope (Perkin Elmer Spectrum GX) was used to analyze the functional groups present in the $\mathrm{P}(3 \mathrm{HB}-\mathrm{co}$ $4 \mathrm{HB})$ copolymer, collagen, and blend scaffolds. The spectra of each sample were obtained in the range of $4000-500 \mathrm{~cm}^{-1}$ at a resolution of $4 \mathrm{~cm}^{-1}$. The spectral outputs were recorded in transmittance as a function of wave number.

2.5. Determination of Amino Groups Using Ninhydrin. The collagen density on the $\mathrm{P}(3 \mathrm{HB}-\mathrm{co}-4 \mathrm{HB}) /$ collagen scaffolds was determined using ninhydrin. Ninhydrin was used as an indicator to qualitatively and quantitatively detect the presence of $\mathrm{NH}_{2}$ groups on the $\mathrm{P}(3 \mathrm{HB}-\mathrm{co}-4 \mathrm{HB}) /$ collagen scaffolds. The scaffolds fabricated were cut into $10 \mathrm{~mm} \times 10 \mathrm{~mm}$ and immersed in $1.0 \mathrm{~mol} / \mathrm{L}$ ninhydrin/ethanol solution. The pieces of scaffolds were later placed in glass tubes and heated at $80^{\circ} \mathrm{C}$ using Memmert water baths (Memmert $\mathrm{GmbH}$, Germany) for 10 mins for accelerating the reaction between ninhydrin and amino groups. Later, $5 \mathrm{~mL}$ of chloroform was quickly added to the tube to dissolve the scaffolds. When the scaffolds displayed purple, 2-propanol $(5 \mathrm{~mL})$ was added to stabilize the blue compound. The OD was measured at $560 \mathrm{~nm}$. A calibration curve using known concentration of 1,6-hexanediamine in chloroform/2-propanol $(1 / 1, \mathrm{v} / \mathrm{v})$ was obtained.

2.6. Organic Elemental Analysis (CHN). The organic elemental analysis is conducted to measure the $\mathrm{C}, \mathrm{H}$, and $\mathrm{N}$ content in the scaffolds fabricated using the CHN Elemental Analyzer 2400 Series II with AD-6 Autobalance (PerkinElmer, USA). The elemental analyzer was operated with constant helium flow as the carrier gas. The heating temperature was maintained constant at 925 for the combustion column and $640^{\circ} \mathrm{C}$ for the reduction column. Approximately $2 \mathrm{mg}$ of sample is used for each measurement. The samples are weighed using AD-6 Autobalance (PerkinElmer, USA). Cystine was used as the standard.

2.7. Water Contact Angle Determination. The contact angles of the fabricated scaffolds were measured using KSV CAM 101 Series Drop Shape Analysis Contact Angle Meter. The scaffolds were placed flat and a droplet of distilled water was placed on the scaffold by pressing the dropper. The drop was observed on the computer screen and the value of the contact angle was calculated using the computer.

2.8. Scanning Electron Microscopy (SEM). The morphologies of the films and scaffolds were also observed using scanning electron microscopy (SEM) (Leo Supra 50 VP Field Mission SEM, Carl-Ziess SMT, Oberkochen, Germany). The dried samples were mounted on aluminium stumps coated with gold in a sputtering device before viewing under the SEM.

2.9. In Vitro Cytotoxicity Evaluation. Various $\mathrm{P}\left(3 \mathrm{HB}-\mathrm{co}^{-}\right.$ $4 \mathrm{HB}) /$ collagen blend scaffolds were cut in size $(6 \mathrm{~mm}$ in diameter) fitting the 96-well flat bottom culture plate and sterilized under GERMICIDE UV Steriliser (CA-MI, Italy) for 1 hour. The scaffolds were then placed in the 96-well flat bottom culture plate. Cells were seeded at $5 \times 10^{4}$ cells $/ \mathrm{mL}$ and were incubated in a $5 \% \mathrm{CO}_{2}$ incubator at $37^{\circ} \mathrm{C}$ for 24 and $72 \mathrm{~h}$. The cells viability and proliferation were assayed with MTS (3-(4,5-dimethylthiazol-2-yl)-5-(3carboxymethoxyphenyl)-2-(4-sulfophenyl)-2H-tetrazolium)/PMS(phenazine methosulfate). 
TABLE 1: Endotoxin levels present in the $\mathrm{P}(3 \mathrm{HB}-c o-4 \mathrm{HB})$ scaffolds recovered by the chloroform extraction method before and after pyrogen removal.

\begin{tabular}{lcc}
\hline Polymer & $\begin{array}{c}\text { Endotoxin before } \\
\text { pyrogen removal } \\
\text { (EU/g) }\end{array}$ & $\begin{array}{c}\text { Endotoxin after } \\
\text { pyrogen removal } \\
(\mathrm{EU} / \mathrm{g})\end{array}$ \\
\hline $\mathrm{P}(3 \mathrm{HB}-c o-20 \% 4 \mathrm{HB})$ & $16 \pm 2$ & $0.5 \pm 0.1$ \\
$\mathrm{P}(3 \mathrm{HB}-c o-35 \% 4 \mathrm{HB})$ & $16 \pm 1$ & $1.0 \pm 0.2$ \\
$\mathrm{P}(3 \mathrm{HB}-c o-50 \% 4 \mathrm{HB})$ & $32 \pm 2$ & $1.0 \pm 0.3$ \\
$\mathrm{P}(3 \mathrm{HB}-c o-82 \% 4 \mathrm{HB})$ & $16 \pm 1$ & $0.5 \pm 0.1$ \\
\hline
\end{tabular}

\section{Results and Discussion}

3.1. Pyrogen Removal. Pyrogen removal was required since PHA polymers produced by Gram-negative bacteria are known to exhibit the presence of endotoxins [12]. The endotoxin levels of the copolymers before and after pyrogen removal are shown in Table 1 . The copolymers recovered by the chloroform extraction method recorded endotoxin levels in the range of 16-32 EU/g. Rapid decrease in endotoxin value was seen after pyrogen removal (0.5-1 EU/g). According to the US Food and Drug Administration guideline, the range of endotoxin permitted in PHA used for medical applications should possess 4-5 EU/g [13]. Therefore, the $\mathrm{P}(3 \mathrm{HB}-\mathrm{co}-4 \mathrm{HB})$ copolymers produced here were suitable for in vivo applications after endotoxin removal.

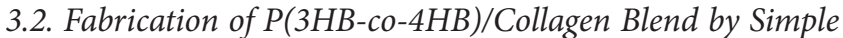
Blending. The fabrication of $\mathrm{P}(3 \mathrm{HB}-\mathrm{co}-4 \mathrm{HB}) /$ collagen blend scaffold was carried out by facile blending combining two different solvents. This method was modified from previous work carried out [14]. Conversely, in another study, a single common solvent was used to dissolve both $\mathrm{P}(3 \mathrm{HB}-$ co- $4 \mathrm{HB})$ and collagen using 1,1,3,3,3-hexafluoro-2-propanol (HFIP) to fabricate $\mathrm{P}(3 \mathrm{HB}-\mathrm{co}-4 \mathrm{HB}) /$ collagen blend by simple blending technique [12]. In fabricating blends, these solvents present a challenge to be completely removed from the scaffolds as strong hydrogen bonds can be formed with the blend. Moreover, recent research has suggested that collagen fibers from HFIP lack native ultrastructure [15]. Thus, a judicious choice of using these two different solvents which could mimic the nature of toxic solvents such as HFIP was used.

Here, two different solvents were combined in the solution processing to fabricate the $\mathrm{P}(3 \mathrm{HB}-\mathrm{co}-4 \mathrm{HB}) /$ collagen blend. The $\mathrm{P}(3 \mathrm{HB}-\mathrm{co}-4 \mathrm{HB})$ copolymer was dissolved in chloroform whereas the collagen which was soluble in acidic solvents was dissolved in glacial acetic acid $(3 \mathrm{~mL})$. Since the organic solvent chloroform was used to dissolve $\mathrm{P}(3 \mathrm{HB}-$ co-4HB), the presence of water was prevented to avoid phase separation in the blend. The volume of acetic acid to chloroform was maintained at $2: 13$ in all the blending process in order to obtain a homogenous solution. The collagen content in the blend scaffold was only up to $15 \mathrm{wt} \%$ as further increment left large holes on the scaffold. This could be due to the fast evaporation rate of $\mathrm{P}(3 \mathrm{HB}-\mathrm{co}-4 \mathrm{HB})$ in chloroform as compared to collagen in acetic acid leaving behind large holes as the amount of collagen increases in the scaffold.
TABLE 2: $\mathrm{CHN}$ analysis of $\mathrm{P}(3 \mathrm{HB}-c o-50 \mathrm{~mol} \% 4 \mathrm{HB}) /$ collagen blends.

\begin{tabular}{lccc}
\hline Polymer & $\begin{array}{c}\text { Carbon } \\
(\%)\end{array}$ & $\begin{array}{c}\text { Hydrogen } \\
(\%)\end{array}$ & $\begin{array}{c}\text { Nitrogen } \\
(\%)\end{array}$ \\
\hline $\mathrm{P}(3 \mathrm{HB}-c o-4 \mathrm{HB})^{\mathrm{a}}$ & 56.24 & 7.25 & 0.0 \\
$\mathrm{P}(3 \mathrm{HB}-c o-4 \mathrm{HB}) / 5$ wt\% collagen & 17.54 & 7.16 & 63.71 \\
$\mathrm{P}(3 \mathrm{HB}-c o-4 \mathrm{HB}) / 10$ wt\% collagen & 15.47 & 6.78 & 68.16 \\
$\mathrm{P}(3 \mathrm{HB}-c o-4 \mathrm{HB}) / 15$ wt\% collagen & 13.65 & 5.43 & 73.87 \\
Cysteine $^{\mathrm{b}}$ & 30.54 & 5.02 & 12.05 \\
\hline
\end{tabular}

${ }^{\mathrm{a}} \mathrm{P}(3 \mathrm{HB}-\mathrm{co}-50 \mathrm{~mol} \% 4 \mathrm{HB})$ was used as control.

${ }^{\mathrm{b}}$ Standard.

3.3. Determination of Surface Chemical Composition on the $P(3 H B-c o-4 H B) / C o l l a g e n$ Blend. The elemental analysis of $\mathrm{C}, \mathrm{H}$, and $\mathrm{N}$ is used to further determine the presence of $\mathrm{N}$ element present in the $\mathrm{P}(3 \mathrm{HB}-$ co- $4 \mathrm{HB}) /$ collagen blend scaffolds. As it is, collagen which is a protein contains $\mathrm{N}$ element, whereas $\mathrm{P}(3 \mathrm{HB}-\mathrm{co}-4 \mathrm{HB})$ does not naturally contain $\mathrm{N}$. Therefore, blending of collagen with $\mathrm{P}(3 \mathrm{HB}-\mathrm{co}-4 \mathrm{HB})$ will result in the presence of $\mathrm{N}$ in $\mathrm{P}(3 \mathrm{HB}-$ co- $4 \mathrm{HB}) /$ collagen blends. Based on Table 2, the incorporation of collagen onto the $\mathrm{P}\left(3 \mathrm{HB}-{ }^{-} o-4 \mathrm{HB}\right)$ by simple blending technique was evident by observing the presence of $\mathrm{N}$ element through $\mathrm{C}, \mathrm{H}$, and $\mathrm{N}$ analysis. The copolymer without the incorporation of collagen did not have the additional nitrogen group. The analysis clearly shows the composition enhancement of $\mathrm{N}$ element in $\mathrm{P}(3 \mathrm{HB}-\mathrm{co}-4 \mathrm{HB}) / 5 \mathrm{wt} \%$ collagen blend scaffolds of $63.71 \%$ as compared to $\mathrm{P}(3 \mathrm{HB}-c o-4 \mathrm{HB})$ copolymer scaffold. Besides that, it was also observed that $\mathrm{P}(3 \mathrm{HB}-\mathrm{co}-4 \mathrm{HB}) /$ collagen blend scaffolds recorded an increase in percentage of $\mathrm{N}$ element as the collagen concentration increased to $15 \mathrm{wt} \%$ recording an increase of 1.15-fold. Similar C, H, and N elemental analysis was carried out previously to determine the presence of $\mathrm{N}$ element on modified silica surface blended with mercaptopropyl [16].

FTIR studies were carried out to monitor chemical modifications on the $\mathrm{P}(3 \mathrm{HB}-c o-4 \mathrm{HB}) /$ collagen blend scaffolds. All peaks corresponding to $\mathrm{P}(3 \mathrm{HB}-\mathrm{co}-4 \mathrm{HB})$ and collagen were observed. Based on the FTIR spectrum in Figure 1(a), collagen was identified based on the presence of amide I band at $1634 \mathrm{~cm}^{-1}$ and amide II band at $1526 \mathrm{~cm}^{-1}$. The broad band at 3300 in collagen is due to N-H stretching [17]. In the natural $\mathrm{P}(3 \mathrm{HB}-\mathrm{co}-4 \mathrm{HB})$ polymer (Figure $1(\mathrm{~b})$ ), the characteristic absorption band at $1720 \mathrm{~cm}^{-1}$ was mainly due to ester carbonyl group $[18,19]$. In $\mathrm{P}(3 \mathrm{HB}-$ co-4HB)/collagen blends, both amides I and II and ester carbonyl group were observed. The spectra of $\mathrm{P}(3 \mathrm{HB}-\mathrm{co}-4 \mathrm{HB}) /$ collagen blends with different collagen concentration of 5-15 wt\% (Figures $1(c)-1(e)$ ) were quite similar to each other but the changes in the content of collagen from 5, 10, and $15 \mathrm{wt} \%$ were revealed in the spectra with the changing proportion of collagen. Prominent change was the change in the amide I and amide II intensity as the collagen intensity increased.

3.4. Hydrophilicity of $\mathrm{P}(3 \mathrm{HB}-\mathrm{co}-4 \mathrm{HB}) /$ Collagen Blend Using Taguchi Method. The hydrophilicity was measured using water contact angle meter. Water contact angle was used to 
TABLE 3: The variables for $\mathrm{P}(3 \mathrm{HB}-\mathrm{co}-4 \mathrm{HB}) /$ collagen blend fabrication using Taguchi method.

\begin{tabular}{lccccc}
\hline Symbol & Scaffold parameters & Level 1 & Level 2 & Level 3 & Level 4 \\
\hline$A$ & Scaffold thickness & 0.1 & 0.2 & - & 50 \\
$B$ & 4HB molar fraction & 20 & 35 & 15 & 82 \\
$C$ & Collagen concentration & 5 & 10 & - \\
\hline
\end{tabular}

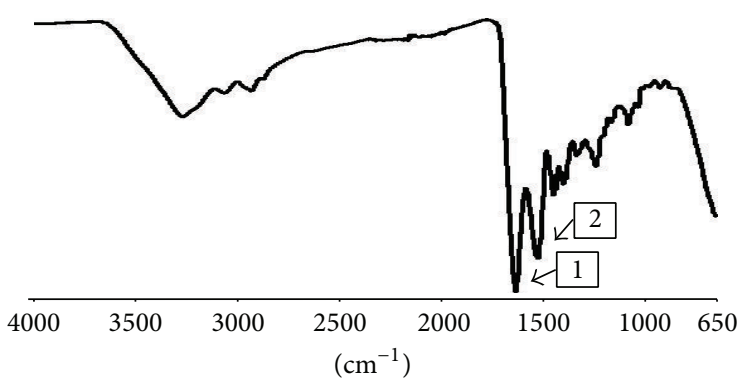

(a)

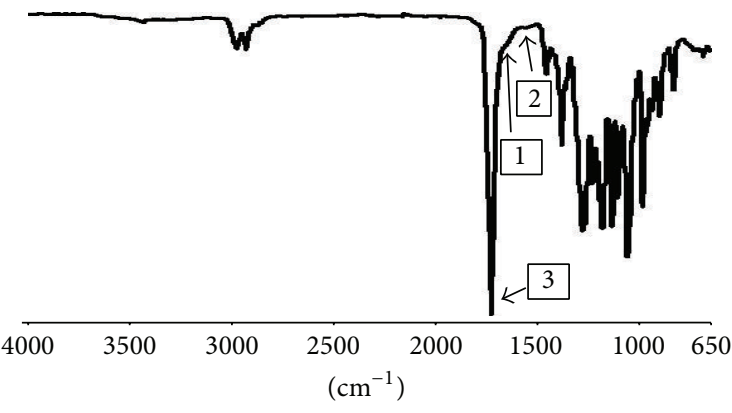

(c)

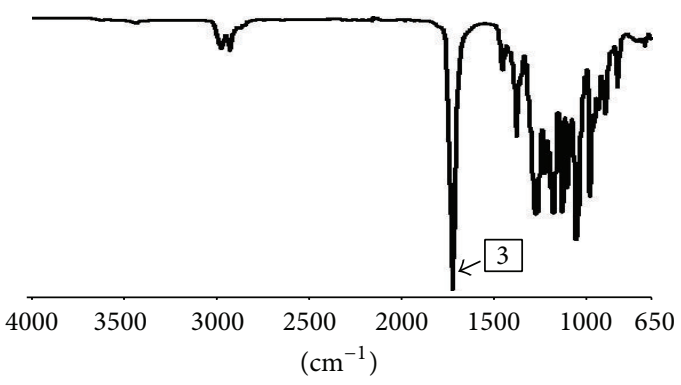

(b)

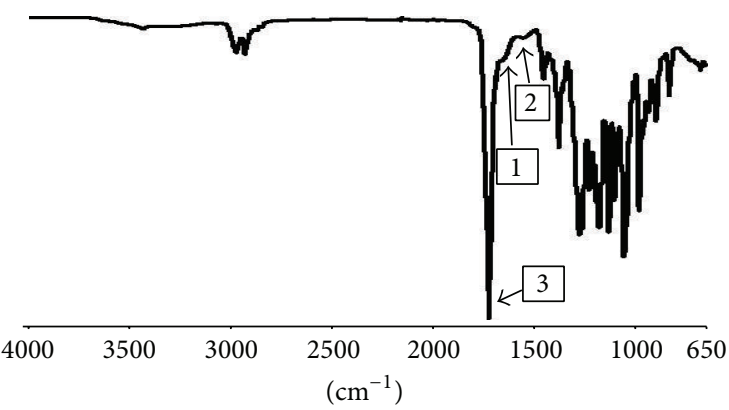

(d)

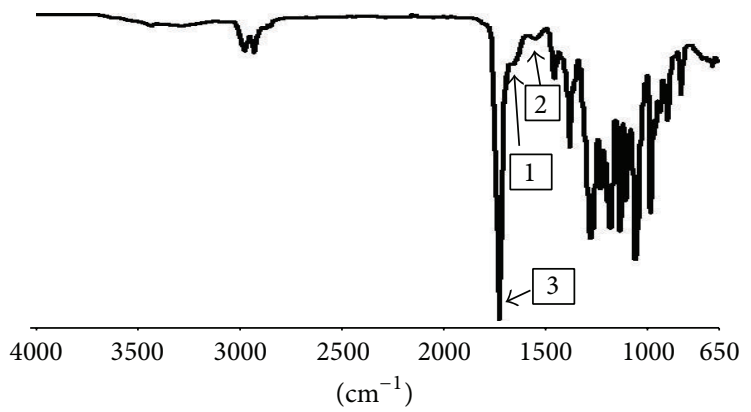

(e)

Figure 1: FTIR spectra of simple blend scaffolds: (a) collagen, (b) $\mathrm{P}(3 \mathrm{HB}-c o-4 \mathrm{HB}),(\mathrm{c}) \mathrm{P}(3 \mathrm{HB}-$ co- $4 \mathrm{HB}) / 5$ wt $\%$ collagen, (d) $\mathrm{P}(3 \mathrm{HB}-c o-$ $4 \mathrm{HB}) / 10 \mathrm{wt} \%$ collagen, and (e) $\mathrm{P}(3 \mathrm{HB}-c o-4 \mathrm{HB}) / 15 \mathrm{wt} \%$ collagen. Arrows 1,2 , and 3 indicate amide I, amide II, and ester group, respectively.

characterize interfacial wetting phenomena which directly relates to the hydrophilicity of a biomaterial [20]. Studies have shown that increase in hydrophilicity is attributed to the possibility of improving the biocompatibility of a biomaterial scaffold [20]. The hydrophilicity of the $\mathrm{P}(3 \mathrm{HB}-$ co-4HB)/collagen blend scaffold was determined using water contact angle analysis. A number of research efforts have shown that comonomer composition [14] and collagen concentration [17] were investigated as potential factors affecting scaffold hydrophilicity. As shown in Table 3, 4HB composition, collagen concentrations, and scaffold thickness were investigated. The scaffold thickness was also considered because a previous study using collagen-chitosan porous scaffold as wound dressing demonstrated scaffold thickness as potential factors improving wound healing [21].

Taguchi method is efficient in designing optimizing parameters over a variety of conditions [22]. Here, Taguchi design of $\mathrm{L}_{32}\left(2^{1} \times 4^{9}\right.$ orthogonal array) was used to analyze the optimum scaffold fabrication parameters to get lowest water contact angle. The dependent variable is water contact angle which denotes hydrophilicity. A total of 32 responses (water contact angle) based on the designed parameters are shown in Table 4. According to the ANOVA results (Table 5), the parameters $4 \mathrm{HB}$ molar fraction and collagen concentration were found to be statistically significant at a confidence level of $95 \%$. 
TABLE 4: Variables of $\mathrm{P}(3 \mathrm{HB}-\mathrm{co}-4 \mathrm{HB}) /$ collagen blend scaffold fabrication and response.

\begin{tabular}{|c|c|c|c|c|}
\hline Run & $\begin{array}{l}\text { Scaffold thickness }(\mathrm{mm}) \\
A\end{array}$ & $\begin{array}{l}\text { 4HB molar fraction }(\mathrm{mol} \%) \\
B\end{array}$ & $\begin{array}{c}\text { Collagen concentration }(5 \mathrm{mg} / \mathrm{mL}) \\
C\end{array}$ & Water contact angle $\left(^{\circ}\right)$ \\
\hline 1 & 0.1 & 35 & 10 & $57.2 \pm 1.7$ \\
\hline 2 & 0.1 & 50 & 0 & $73.2 \pm 1.2$ \\
\hline 3 & 0.2 & 35 & 15 & $51.3 \pm 0.9$ \\
\hline 4 & 0.1 & 20 & 5 & $80.1 \pm 1.1$ \\
\hline 5 & 0.2 & 20 & 15 & $64.0 \pm 1.3$ \\
\hline 6 & 0.2 & 50 & 5 & $68.3 \pm 0.5$ \\
\hline 7 & 0.1 & 20 & 15 & $62.3 \pm 1.6$ \\
\hline 8 & 0.1 & 20 & 0 & $81.2 \pm 1.3$ \\
\hline 9 & 0.2 & 82 & 0 & $53.2 \pm 1.0$ \\
\hline 10 & 0.1 & 50 & 5 & $68.9 \pm 1.2$ \\
\hline 11 & 0.1 & 50 & 15 & $44.5 \pm 1.1$ \\
\hline 12 & 0.1 & 35 & 15 & $52.4 \pm 1.3$ \\
\hline 13 & 0.2 & 50 & 15 & $61.3 \pm 1.7$ \\
\hline 14 & 0.1 & 82 & 10 & $49.2 \pm 1.6$ \\
\hline 15 & 0.2 & 20 & 10 & $74.1 \pm 0.8$ \\
\hline 16 & 0.2 & 82 & 15 & $48.1 \pm 1.3$ \\
\hline 17 & 0.2 & 50 & 0 & $69.8 \pm 1.4$ \\
\hline 18 & 0.2 & 20 & 0 & $79.8 \pm 1.1$ \\
\hline 19 & 0.2 & 20 & 5 & $77.5 \pm 1.2$ \\
\hline 20 & 0.2 & 82 & 10 & $53.0 \pm 1.8$ \\
\hline 21 & 0.1 & 50 & 10 & $64.6 \pm 1.3$ \\
\hline 22 & 0.2 & 35 & 5 & $73.3 \pm 1.7$ \\
\hline 23 & 0.2 & 35 & 0 & $76.6 \pm 0.6$ \\
\hline 24 & 0.2 & 35 & 10 & $64.3 \pm 0.9$ \\
\hline 25 & 0.2 & 82 & 5 & $51.9 \pm 0.6$ \\
\hline 26 & 0.1 & 35 & 5 & $63.3 \pm 1.1$ \\
\hline 27 & 0.1 & 82 & 5 & $55.2 \pm 1.3$ \\
\hline 28 & 0.2 & 50 & 10 & $68.7 \pm 1.6$ \\
\hline 29 & 0.1 & 82 & 0 & $56.7 \pm 1.9$ \\
\hline 30 & 0.1 & 82 & 15 & $45.4 \pm 1.3$ \\
\hline 31 & 0.1 & 35 & 0 & $78.4 \pm 1.5$ \\
\hline 32 & 0.1 & 20 & 10 & $73.6 \pm 1.7$ \\
\hline
\end{tabular}

TABLE 5: ANOVA for P(3HB-co-4HB)/collagen blend fabrication.

\begin{tabular}{|c|c|c|c|c|c|c|c|}
\hline & $\mathrm{SS}^{\mathrm{a}}$ & d.f. & $\mathrm{MS}^{\mathrm{b}}$ & $F$ value & $\begin{array}{l}\text { Prob. } \\
>F\end{array}$ & $\begin{array}{c}\text { Contribution } \\
\% \\
\end{array}$ & \\
\hline Model & 4009.49 & 22 & 182.25 & 8.91 & 0.0010 & - & Significant \\
\hline$A$ & 64.70 & 1 & 64.70 & 3.16 & 0.1091 & 1.61 & \\
\hline$B$ & 2041.94 & 3 & 680.65 & 33.27 & $<0.0001$ & 50.93 & \\
\hline$C$ & 1476.01 & 3 & 492.00 & 24.05 & 0.0001 & 36.81 & \\
\hline$A B$ & 98.95 & 3 & 32.98 & 1.61 & 0.2541 & 2.47 & \\
\hline$A C$ & 119.57 & 3 & 39.86 & 1.95 & 0.1925 & 2.98 & \\
\hline$B C$ & 208.32 & 9 & 23.15 & 1.13 & 0.4285 & 5.2 & \\
\hline Residual & 184.12 & 9 & 20.46 & & & & \\
\hline Cor. total & 4193.61 & 31 & & & & & \\
\hline
\end{tabular}

${ }^{\mathrm{a}}$ Sum square.

${ }^{\mathrm{b}}$ Mean square.

$\%$ contribution $=$ SS/total of SS. 


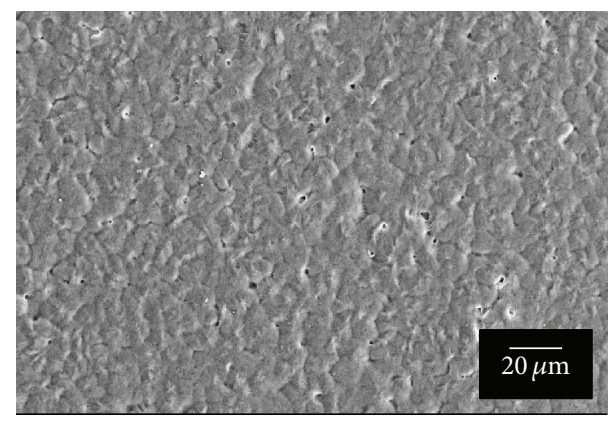

(a)

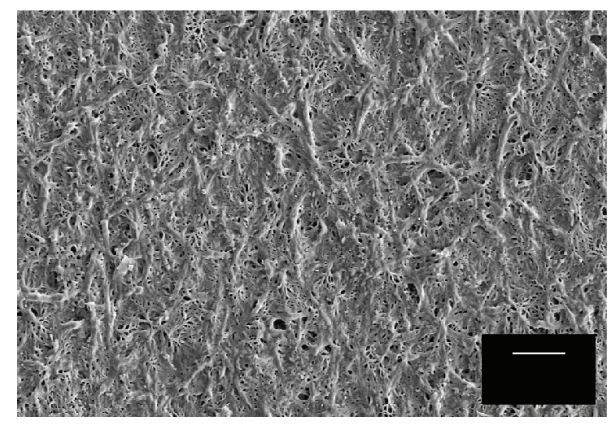

(c)

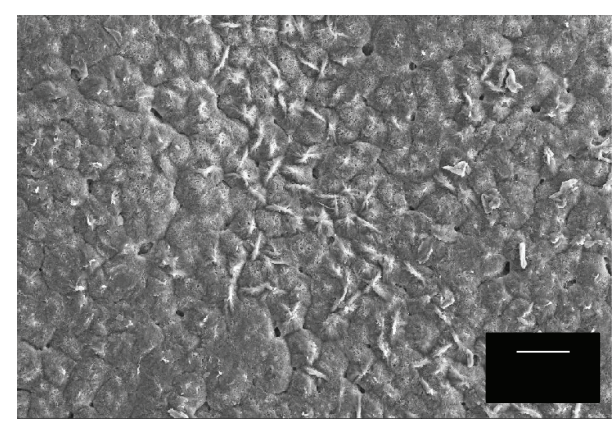

(b)

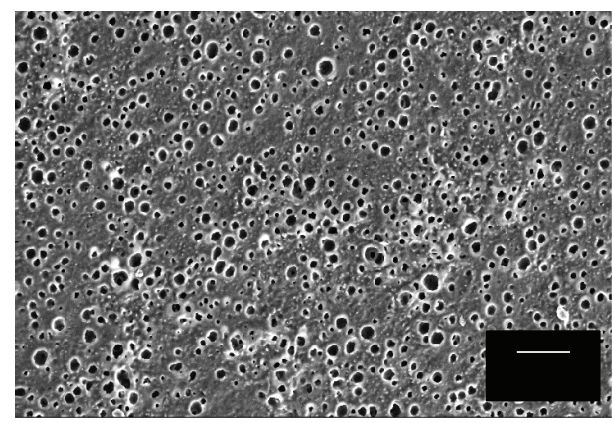

(d)

Figure 2: SEM images of surface morphology of (a) $\mathrm{P}(3 \mathrm{HB}-\mathrm{co}-50 \mathrm{~mol} \% 4 \mathrm{HB})$, (b) $\mathrm{P}(3 \mathrm{HB}-\mathrm{co}-50 \mathrm{~mol} \% 4 \mathrm{HB}) / 5 \mathrm{wt} \%$ collagen, (c) $\mathrm{P}(3 \mathrm{HB}-\mathrm{co}-$ $50 \mathrm{~mol} \% 4 \mathrm{HB}) / 10 \mathrm{wt} \%$ collagen, and (d) $\mathrm{P}(3 \mathrm{HB}-$ co $-50 \mathrm{~mol} \% 4 \mathrm{HB}) / 15 \mathrm{wt} \%$ collagen.

However, it is evident that $4 \mathrm{HB}$ molar fraction contributes the highest with $50.93 \%$ to the water contact angle of the scaffold. The collagen concentration is the next contributing factor having $36.81 \%$ on water contact angle. Nevertheless, the result showed there were no significant interactions between the parameters tested.

The factorial analysis gave a predictive model which formed as an equation obtained by the Taguchi method shown as

$$
\begin{aligned}
& \text { Water contact angle }=+64.16+0.54 * A+9.92 \\
& * B[1]+0.44 * B[2]+2.21 \\
& * B[3]+6.96 * C[1]+3.56 \\
& \text { * } C[2]-1.07 * C[3]-0.77 \\
& * A B[1]+1.23 * A B[2] \\
& +0.12 * A B[3]-1.81 \\
& \text { *AC [1] }-0.51 * A C[2] \\
& +1.39 * A C[3]-0.53 \\
& \text { * B [1] } C[1]+5.94 \\
& \text { *B [2] } C[1]-1.82 \\
& \text { * } B[3] C[1]+1.17 \\
& * B[1] C[2]+0.14 \\
& * B[2] C[2]+0.28
\end{aligned}
$$

$$
\begin{aligned}
& * B[3] C[2]+0.84 \\
& * B[1] C[3]-2.78 \\
& * B[2] C[3]+1.36 \\
& * B[3] C[3] .
\end{aligned}
$$

Based on the results generated using the Taguchi method, $\mathrm{P}(3 \mathrm{HB}-\mathrm{co}-50 \mathrm{~mol} \% 4 \mathrm{HB}) / 15 \mathrm{wt} \%$ collagen with $0.1 \mathrm{~mm}$ thickness recorded the lowest water contact angle of $44.5^{\circ}$. This was further proved by the SEM analysis carried out to determine the surface morphologies of the scaffolds. It was observed that the $\mathrm{P}(3 \mathrm{HB}-\mathrm{co}-50 \mathrm{~mol} \% 4 \mathrm{HB}) / 15 \mathrm{wt} \%$ collagen blend surface (Figure 2(d)) has more irregular large open pores with rougher surfaces as compared to the other $\mathrm{P}(3 \mathrm{HB}-\mathrm{co}-4 \mathrm{HB}) /$ collagen blend surface (Figures $2(\mathrm{a})-2(\mathrm{c})$ ). The $\mathrm{P}(3 \mathrm{HB}-\mathrm{co}-50 \mathrm{~mol} \% 4 \mathrm{HB}) / 5 \mathrm{wt} \%$ and $\mathrm{P}(3 \mathrm{HB}-\mathrm{co}-50 \mathrm{~mol} \%$ $4 \mathrm{HB}) / 10 \mathrm{wt} \%$ collagen blend surfaces were wave-like with small closed-pores probably resulting from the evaporation of solvent during the fabrication of the scaffold. However, it was evident that $\mathrm{P}(3 \mathrm{HB}-\mathrm{co}-4 \mathrm{HB})$ scaffold surface becomes more porous after blending. Rougher surface was observed as the collagen concentration increased from 5 to $15 \mathrm{wt} \%$ as compared to $\mathrm{P}(3 \mathrm{HB}-\mathrm{co}-4 \mathrm{HB})$ scaffold without collagen (Figures $2(\mathrm{a})-2(\mathrm{~d})$ ). Previous research exhibited porous $\mathrm{P}(3 \mathrm{HB}-$ co-4HB) scaffolds with improved wettability after blending with collagen [12]. Thus, the surface porosity increases and at the same time increases the surface area of the scaffolds which contributes to enclosing large amount of water on the surface. However, the fast evaporation of chloroform as compared to 


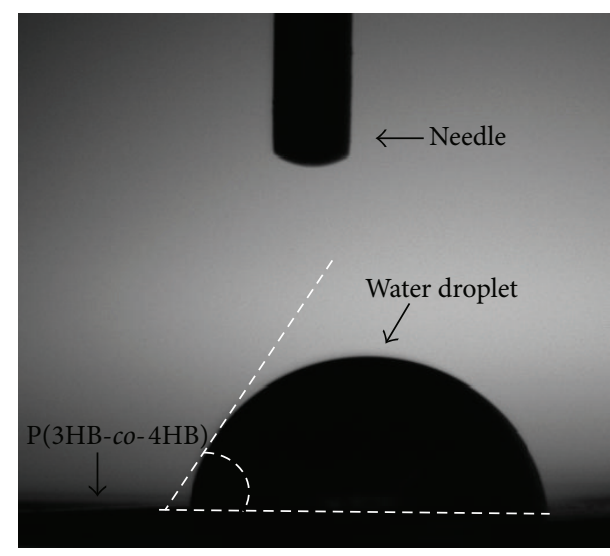

(a)

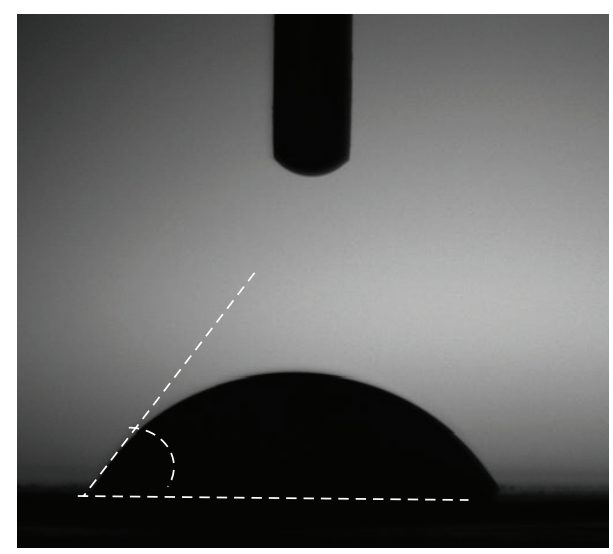

(c)

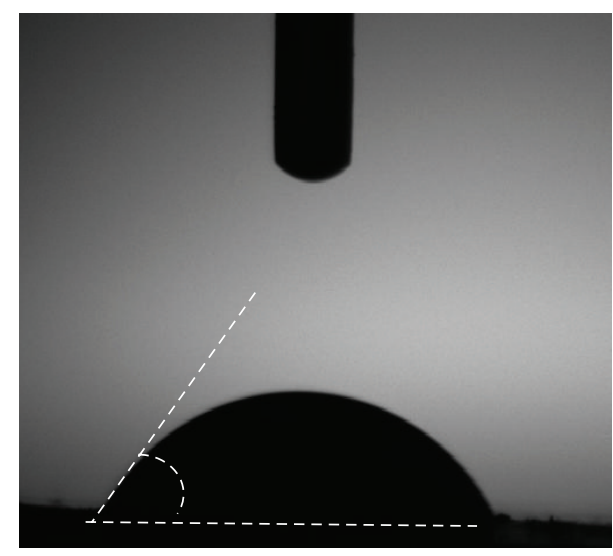

(b)

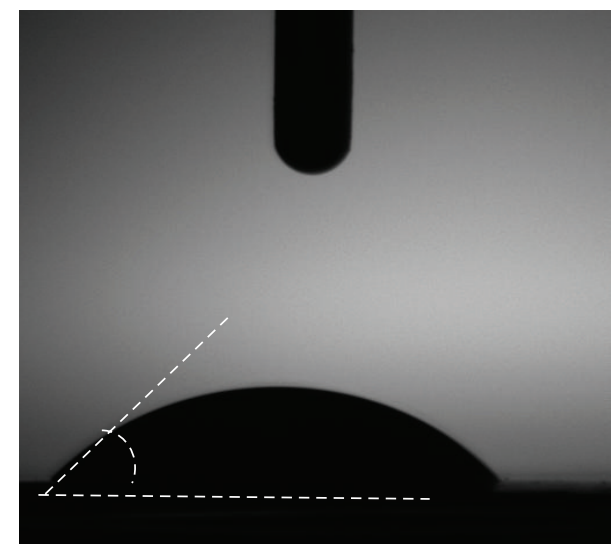

(d)

Figure 3: Sessile drops for static water contact angle measurement of $0.1 \mathrm{~mm}$ thick (a) $\mathrm{P}(3 \mathrm{HB}-\mathrm{co}-50 \mathrm{~mol} \% 4 \mathrm{HB})$ (control) [73.2 $2^{\circ}$, (b) $\mathrm{P}(3 \mathrm{HB}-c o-50 \mathrm{~mol} \% 4 \mathrm{HB}) / 5 \mathrm{mg}$ collagen $\left[68.9^{\circ}\right]$, (c) $\mathrm{P}(3 \mathrm{HB}-c o-50 \mathrm{~mol} \% 4 \mathrm{HB}) / 10 \mathrm{mg}$ collagen $\left[64.6^{\circ}\right]$, and (d) $\mathrm{P}(3 \mathrm{HB}-c o-50 \mathrm{~mol} \% 4 \mathrm{HB}) / 15 \mathrm{mg}$ collagen $\left[44.5^{\circ}\right]$.

the acetic acid used in fabricating the blend left large visible holes on the scaffold blends.

Figures 3(a)-3(d) show the static contact angles for water drops on $0.1 \mathrm{~mm}$ thick $\mathrm{P}(3 \mathrm{HB}-c o-50 \mathrm{~mol} \% 4 \mathrm{HB}), \mathrm{P}(3 \mathrm{HB}-$ co-50 mol\% 4HB $) / 5 \mathrm{wt} \%$ collagen, $\mathrm{P}(3 \mathrm{HB}-$ co- $50 \mathrm{~mol} \%$ $4 \mathrm{HB}) / 10 \mathrm{wt} \%$ collagen, and $\mathrm{P}(3 \mathrm{HB}-\mathrm{co}-50 \mathrm{~mol} \% 4 \mathrm{HB}) / 15 \mathrm{wt} \%$ collagen blends. The static water contact angles of water for the various substrates were measured in various sample locations. The decrease in contact angle from $\mathrm{P}(3 \mathrm{HB}-\mathrm{co}$ $50 \mathrm{~mol} \% 4 \mathrm{HB})$ to $\mathrm{P}(3 \mathrm{HB}-\mathrm{co}-50 \mathrm{~mol} \% 4 \mathrm{HB}) / 15 \mathrm{wt} \%$ collagen was evident. The contact angle is quantified as the angle formed by the intersection of the liquid-solid interface. Figure $3(\mathrm{~d})$ shows the smallest contact angle $\left(44.5^{\circ}\right)$ as the water droplet spreads on the surface as compared to the large contact angle observed in Figure 3(a) $\left[73.2^{\circ}\right]$ when the water droplet beaded on the surface. It can be seen that as the collagen concentration increases, the water contact angle decreases.

3.5. Biocompatibility and Cytotoxicity of $\mathrm{P}(3 \mathrm{HB}-\mathrm{co}-4 \mathrm{HB}) / \mathrm{Col}-$ lagen Blend Scaffolds via In Vitro Cell Proliferation. The ability to support attachment and promote proliferation of cultured cells is a prerequisite of a functional biomedical scaffold. In order to evaluate cellular behavior or cell growth, L929 fibroblasts cells were seeded onto the various $\mathrm{P}(3 \mathrm{HB}-$ co-4HB)/collagen blend scaffolds fabricated. In general L929 cell numbers increased on all scaffolds over the time period of 3 days as compared to the initial seeding. Incorporation of collagen was found to further improve cytocompatibility. Cell counts on collagen blends improved greatly compared with those without collagen (Figure 4). This was also evident with increasing collagen concentration recording highest proliferation rate of cells with scaffolds blend of $15 \mathrm{wt} \%$ collagen. This can be attributed to the fact that collagen has high water affinity, low antigenicity, and a key element in extracellular matrix (ECM) which contributes to the good cell compatibility [23]. This was further supported by previous research which reported collagen to stimulate differentiation of cartilage tissue [24]. The $\mathrm{P}(3 \mathrm{HB}-\mathrm{co}$ $50 \mathrm{~mol} \% 4 \mathrm{HB}) /$ collagen blend scaffold showed significantly higher proliferation rate with various collagen concentration than other scaffold blends. At $15 \mathrm{wt} \%$ collagen concentration, $0.1 \mathrm{~mm}$ thick and $0.2 \mathrm{~mm} \mathrm{P}(3 \mathrm{HB}-\mathrm{co}-50 \mathrm{~mol} \% 4 \mathrm{HB}) /$ collagen blend scaffold measured a significantly higher cell number ( $>1.62$-fold and $>1.38$-fold, resp.) than the initial seeding for the L929. 


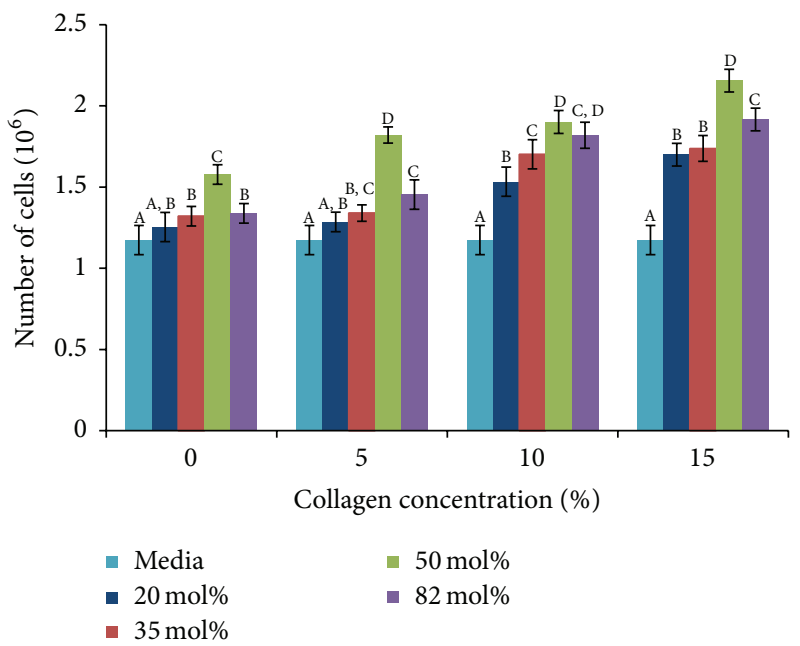

(a)

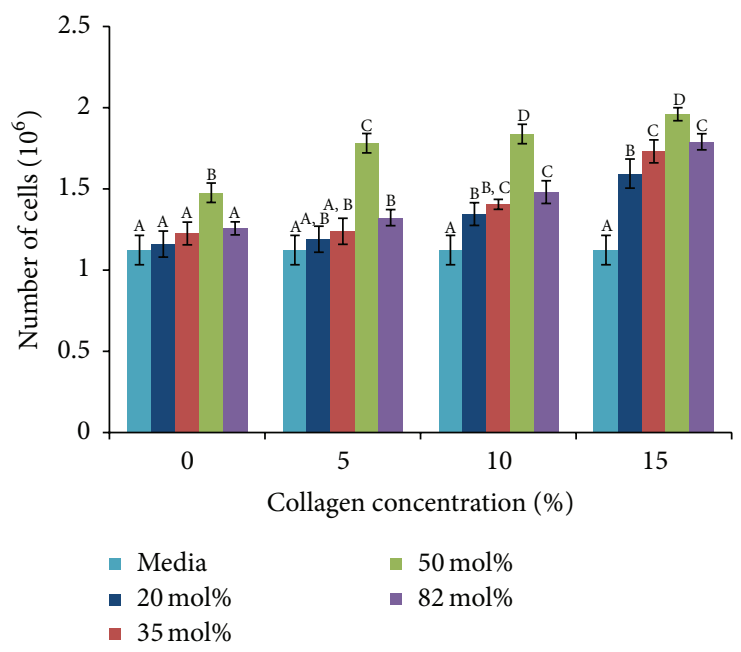

(b)

FIGURE 4: (a) Proliferation of L929 cells on day 3 seeded on the various $\mathrm{P}(3 \mathrm{HB}-\mathrm{co}-4 \mathrm{HB}) /$ collagen blend scaffold of varying collagen concentration with $0.1 \mathrm{~mm}$ thickness. Values are mean of four replicates. Mean data accompanied by different alphabets indicates significant difference within the group (Tukey's HSD test, $p<0.05)$. (b) Proliferation of L929 cells on day 3 seeded on the various $\mathrm{P}(3 \mathrm{HB}-\mathrm{co}-$ $4 \mathrm{HB} /$ /collagen blend scaffold of varying collagen concentration with $0.2 \mathrm{~mm}$ thickness. Values are mean of four replicates. Mean data accompanied by different alphabets indicates significant difference within the group (Tukey's HSD test, $p<0.05$ ).

Proliferation of cells on the PHA scaffolds increased in the order of $\mathrm{P}(3 \mathrm{HB}-\mathrm{co}-20 \mathrm{~mol} \% 4 \mathrm{HB})<\mathrm{P}(3 \mathrm{HB}-c o-35 \% 4 \mathrm{HB})<$ $\mathrm{P}(3 \mathrm{HB}-\mathrm{co}-82 \mathrm{~mol} \% 4 \mathrm{HB})<\mathrm{P}(3 \mathrm{HB}-\mathrm{co}-50 \mathrm{~mol} \% 4 \mathrm{HB})$ for both 0.1 and $0.2 \mathrm{~mm}$ scaffold thickness. The results correlate with the similar pattern of increase in hydrophilicity. The highest hydrophilicity of $44.5^{\circ}$ (Figure $3(\mathrm{~d})$ ) is recorded by $\mathrm{P}(3 \mathrm{HB}-\mathrm{co}-50 \mathrm{~mol} \% 4 \mathrm{HB}) / 15 \mathrm{mg}$ collagen blend scaffold. Interestingly, the fibroblast cell proliferation was also found to be influenced by the thickness of the scaffolds. It can be observed that $0.1 \mathrm{~mm}$ thick $\mathrm{P}(3 \mathrm{HB}-\mathrm{co}-4 \mathrm{HB}) /$ collagen blend scaffold showed an increase in proliferation rate as compared to $0.2 \mathrm{~mm}$ collagen scaffolds for L929 fibroblast cells (Figures $4(\mathrm{a})$ and $4(\mathrm{~b}))$. The results indicate that optimization of film thickness could produce significant enhancements in initial adhesion and subsequent growth of the L929 cells. Similar observation has been reported earlier where growth rate of human aortic endothelial cells (HAEC) on poly(vinylacetic acid) scaffold was dependent on film thickness and cell proliferation increased as the film thickness decreased to $0.2 \times$ $10^{-3} \mathrm{~mm}$ [25]. It has been reported that degree of roughness could increase protein adsorption and cell attachment, hence providing anchorage as well as space for cell growth [26]. Notably, surface roughness greatly influences the interactions between cells and materials [27]. The surface morphology observed with SEM analysis also indicated a rough and porous surface of $\mathrm{P}(3 \mathrm{HB}-\mathrm{co}-50 \mathrm{~mol} \% 4 \mathrm{HB}) / 15 \mathrm{mg}$ collagen blend scaffold (Figure 2(d)) which explains the highest hydrophilicity, thus contributing to the highest proliferation rate on this collagen blend scaffold (Figure 5).

\section{Conclusion}

Collagen was incorporated onto the $\mathrm{P}(3 \mathrm{HB}-\mathrm{co}-4 \mathrm{HB})$ copolymer to enhance the hydrophilicity for application in tissue

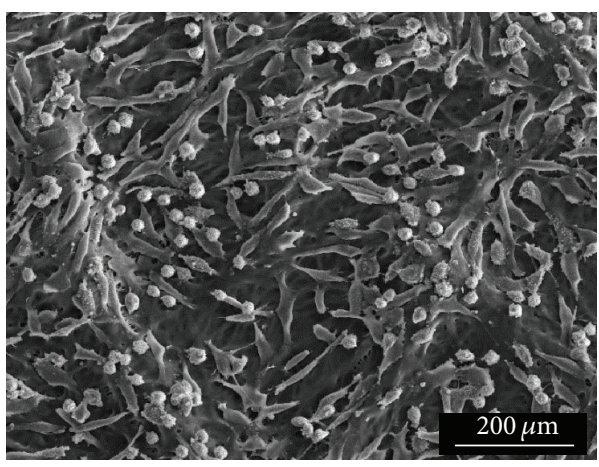

FIGURE 5: SEM micrographs of proliferation of L929 cells on $\mathrm{P}(3 \mathrm{HB}-$ co-50 mol\% $4 \mathrm{HB}) / 15 \mathrm{mg}$ collagen.

engineering. Dual solvent system was adapted to minimize the use of toxic solvents. FTIR, CHN analysis, and SEM analysis were carried out to further confirm the modification process. Various parameters such as collagen concentration, thickness of the scaffold, and $4 \mathrm{HB}$ molar fraction were investigated in fabricating a scaffold with increases of hydrophilicity as an ideal scaffold material in tissue engineering. The parameters were optimized using Taguchi method. It can be deduced that the $\mathrm{P}(3 \mathrm{HB}-\mathrm{co}-$ $4 \mathrm{HB}) /$ collagen blend scaffold with increased collagen concentration of up to $15 \mathrm{wt} \%$, with molar fraction of $50 \mathrm{~mol} \%$ and thickness of $0.1 \mathrm{~mm}$, increased hydrophilicity and thus increased the L929 cell proliferation on the surface. This study shows that surface modification by blending biomacromolecules can enhance the biocompatibility of a polymeric material. 


\section{Conflict of Interests}

The authors declare that there is no conflict of interests regarding the publication of this paper.

\section{Acknowledgment}

The authors thank Ministry of Science, Technology and Innovation (MOSTI) for the e-science fund financial support (Grant no. 02-05-23-SF0003).

\section{References}

[1] Y. P. Jiao and F. Z. S. Cui, "Surface modification of polyester biomaterials for tissue engineering," Biomedical Materials, vol. 2, no. 4, pp. 24-37, 2007.

[2] S. F. Williams, D. P. Martin, D. M. Horowitz, and O. P. Peoples, "PHA applications: addressing the price performance issue I. Tissue engineering," International Journal of Biological Macromolecules, vol. 25, no. 1-3, pp. 111-121, 1999.

[3] T. H. Ying, D. Ishii, A. Mahara et al., "Scaffolds from electrospun polyhydroxyalkanoate copolymers: fabrication, characterization, bioabsorption and tissue response," Biomaterials, vol. 29, no. 10, pp. 1307-1317, 2008.

[4] D. P. Martin and S. F. Williams, "Medical applications of poly4-hydroxybutyrate: a strong flexible absorbable biomaterial," Biochemical Engineering Journal, vol. 16, no. 2, pp. 97-105, 2003.

[5] S. Rathbone, P. Furrer, J. Lübben, M. Zinn, and S. Cartmell, "Biocompatibility of polyhydroxyalkanoate as a potential material for ligament and tendon scaffold material," Journal of Biomedical Materials Research Part A, vol. 93, no. 4, pp. 13911403, 2010.

[6] F. J. O. Brien, "Biomaterials \& scaffolds for tissue engineering," Materials Today, vol. 14, no. 3, pp. 88-95, 2011.

[7] S. M. Rezaei and Z. A. Mohd Ishak, "Grafting of collagen onto interpenetrating polymer networks of poly(2-hydroxyethyl methacrylate) and poly(dimethyl siloxane) polymer films for biomedical applications," Express Polymer Letters, vol. 8, no. 1, pp. 39-49, 2014.

[8] S. D. Gorham, S. Srivastava, D. A. French, and R. Scott, "The effect of gamma-ray and ethylene oxide sterilization on collagen-based wound-repair materials," Journal of Materials Science: Materials in Medicine, vol. 4, no. 1, pp. 40-49, 1993.

[9] Y.-Y. Wang, L.-X. Lü, J.-C. Shi, H.-F. Wang, Z.-D. Xiao, and N.P. Huang, "Introducing RGD peptides on PHBV films through PEG-containing cross-linkers to improve the biocompatibility," Biomacromolecules, vol. 12, no. 3, pp. 551-559, 2011.

[10] D. I. Zeugolis, S. T. Khew, E. S. Y. Yew et al., "Electro-spinning of pure collagen nano-fibres-just an expensive way to make gelatin?" Biomaterials, vol. 29, no. 15, pp. 2293-2305, 2008.

[11] A. A. Amirul, A. R. M. Yahya, K. Sudesh, M. N. M. Azizan, and M. I. A. Majid, "Biosynthesis of poly(3-hydroxybutyrate-co-4hydroxybutyrate) copolymer by Cupriavidus sp. USMAA1020 isolated from Lake Kulim, Malaysia," Bioresource Technology, vol. 99, no. 11, pp. 4903-4909, 2008.

[12] U. Rao, R. Kumar, S. Balaji, and P. K. Sehgal, "A novel biocompatible poly(3-hydroxy-co-4-hydroxybutyrate) blend as a potential biomaterial for tissue engineering," Journal of Bioactive and Compatible Polymers, vol. 26, pp. 452-463, 2011.
[13] S. Y. Lee, J.-I. Choi, K. Han, and J. Y. Song, "Removal of endotoxin during purification of poly(3-hydroxybutyrate) from gram-negative bacteria," Applied and Environmental Microbiology, vol. 65, no. 6, pp. 2762-2764, 1999.

[14] M. Rennukka and A. A. Amirul, "Fabrication of poly(3hydroxybutyrate-co-4-hydroxybutyrate)/chitosan blend material: synergistic effects on physical, chemical, thermal and biological properties," Polymer Bulletin, vol. 70, no. 6, pp. 19371957, 2013.

[15] B. Dong, O. Arnoult, M. E. Smith, and G. E. Wnek, "Electrospinning of collagen nanofiber scaffolds from benign solvents," Macromolecular Rapid Communications, vol. 30, no. 7, pp. 539$542,2009$.

[16] N. H. Khdary, M. A. Ghanem, M. G. Merajuddine, and F. M. Bin Manie, "Incorporation of $\mathrm{Cu}, \mathrm{Fe}, \mathrm{Ag}$, and $\mathrm{Au}$ nanoparticles in mercapto-silica (MOS) and their $\mathrm{CO}_{2}$ adsorption capacities," Journal of $\mathrm{CO}_{2}$ Utilization, vol. 5, pp. 17-23, 2014.

[17] L.-Y. Wang, Y.-J. Wang, and D.-R. Cao, "Surface modification of poly(3-hydroxybutyrate-co-3-hydroxyvalerate) membrane by combining surface aminolysis treatment with collagen immobilization," Journal of Macromolecular Science, Part A: Pure and Applied Chemistry, vol. 46, no. 8, pp. 765-773, 2009.

[18] N. Nagiah, L. Madhavi, R. Anitha, N. T. Srinivasan, and U. T. Sivagnanam, "Electrospinning of poly(3-hydroxybutyric acid) and gelatin blended thin films: fabrication, characterization, and application in skin regeneration," Polymer Bulletin, vol. 70, no. 8, pp. 2337-2358, 2013.

[19] K. Kansiz, H. Billman-Jacobe, and D. McNaughton, "Quantitative determination of the biodegradable polymer $\operatorname{poly}(\beta$ hydroxybutyrate) in a recombinant Escherichia coli strain by use of mid-infrared spectroscopy and multivariative statistics," Applied and Environmental Microbiology, vol. 66, no. 8, pp. 3415-3420, 2000.

[20] H. P. S. Abdul Khalil and N. L. Suraya, "Anhydride modification of cultivated kenaf bast fibers: morphological, spectroscopic, and thermal studies," BioResources, vol. 6, no. 2, pp. 1122-1135, 2011.

[21] S. Haifei, W. Xingang, W. Shoucheng, M. Zhengwei, Y. Chuangang, and H. Chunmao, "The effect of collagen-chitosan porous scaffold thickness on dermal regeneration in a onestage grafting procedure," Journal of the Mechanical Behavior of Biomedical Materials, vol. 29, pp. 114-125, 2014.

[22] A. Canakci, F. Erdemir, T. Varol, and A. Patir, "Determining the effect of process parameters on particle size in mechanical milling using the Taguchi method: measurement and analysis," Measurement, vol. 46, no. 9, pp. 3532-3540, 2013.

[23] S. A. Sell, M. J. McClure, K. Garg, P. S. Wolfe, and G. L. Bowlin, "Electrospinning of collagen/biopolymers for regenerative medicine and cardiovascular tissue engineering," Advanced Drug Delivery Reviews, vol. 61, no. 12, pp. 1007-1019, 2009.

[24] J. Glowacki and S. Mizuno, "Collagen scaffolds for tissue engineering," Biopolymers, vol. 89, no. 5, pp. 338-344, 2008.

[25] D. Bhattacharyya, H. Xu, R. R. Deshmukh, R. B. Timmons, and K. T. Nguyen, "Surface chemistry and polymer film thickness effects on endothelial cell adhesion and proliferation," Journal of Biomedical Materials Research Part A, vol. 94, no. 2, pp. 640$648,2010$. 
[26] Y.-J. Hu, X. Wei, W. Zhao, Y.-S. Liu, and G.-Q. Chen, "Biocompatibility of poly(3-hydroxybutyrate-co-3-hydroxyvalerate-co3-hydroxyhexanoate) with bone marrow mesenchymal stem cells," Acta Biomaterialia, vol. 5, no. 4, pp. 1115-1125, 2009.

[27] Y.-S. Liang, W. Zhao, and G.-Q. Chen, "Study on the biocompatibility of novel terpolyester poly(3-hydroxybutyrate-co-3hydroxyvalerate-co-3-hydroxyhexanoate)," Journal of Biomedical Materials Research Part A, vol. 87, no. 2, pp. 441-449, 2008. 

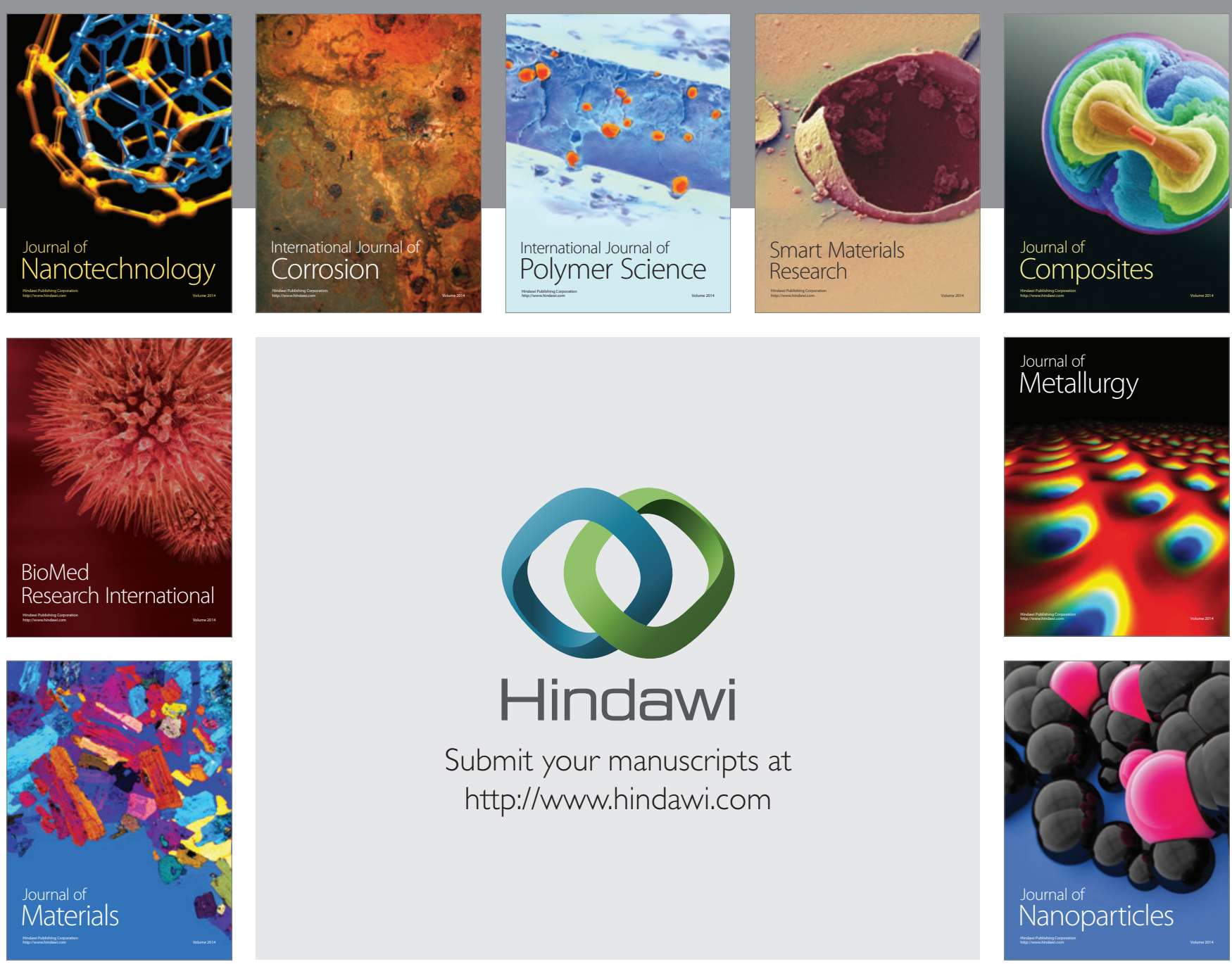

Submit your manuscripts at http://www.hindawi.com
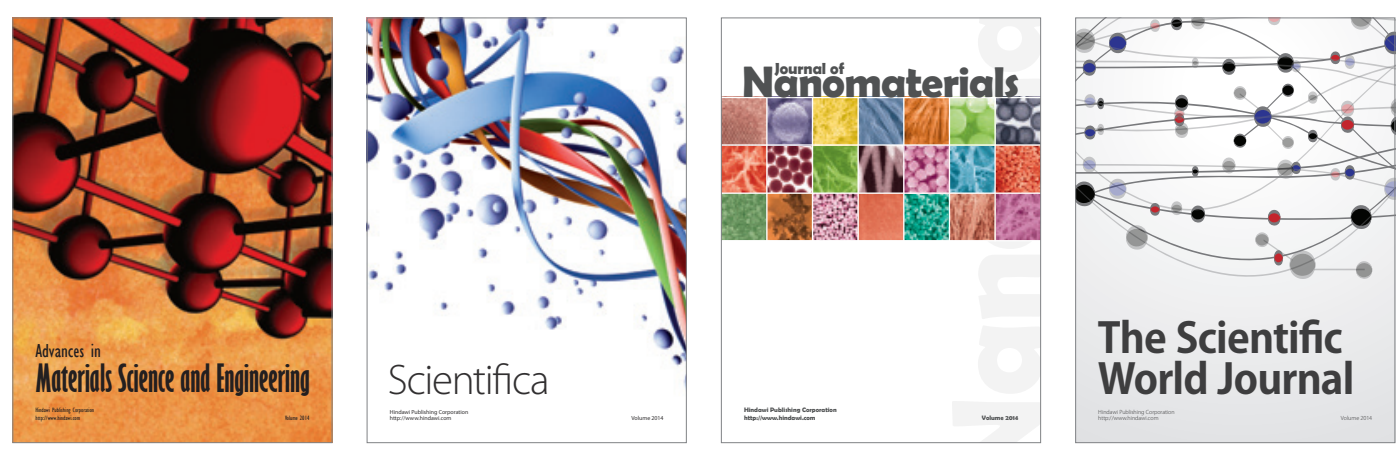

\section{The Scientific World Journal}
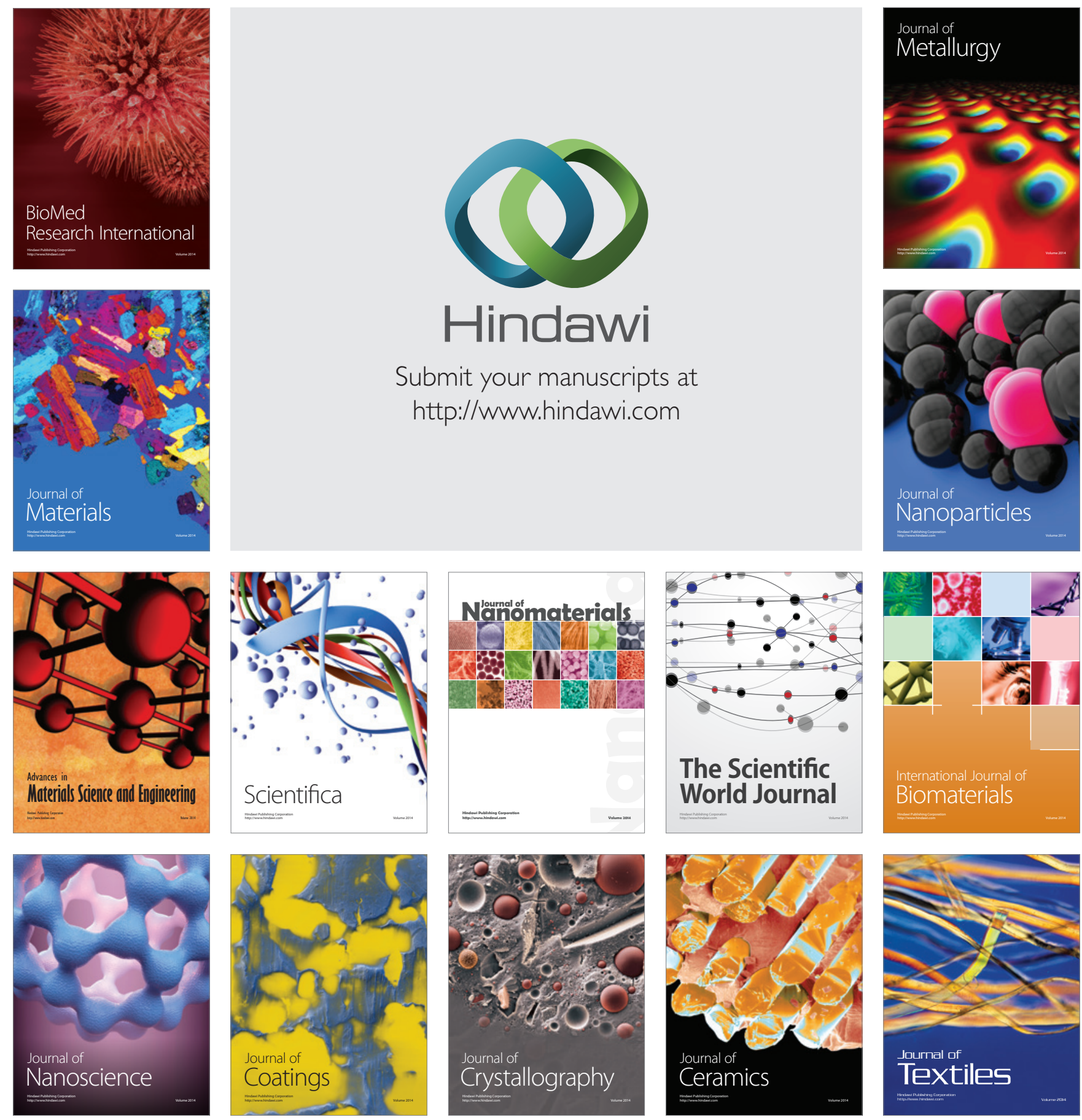